\title{
Aspek Kerentanan Usaha Ternak Sapi Perah di Kabupaten Malang
}

\author{
Amam $^{a}$, Pradiptya Ayu Harsita \\ ${ }^{a}$ Fakultas Pertanian, Universitas Jember, Jember-Jawa Timur, Indonesia. Email: amam.faperta@unej.ac.id \\ ${ }^{b}$ Fakultas Pertanian, Universitas Jember, Jember-Jawa Timur, Indonesia. Email: pradiptya@unej.ac.id
}

\section{Article Info}

\section{Article history:}

Received 2 April 2019

Received in revised form 15 April 2019

Accepted 26 April 2019

DOI:

https://doi.org/10.32938/ag.v4i2.663

\section{Keywords}

Sapi Perah

Aspek

Kelembagaan Peternak

Pengembangan Usaha Ternak

\section{Abstrak}

Kerentanan dalam usaha ternak sapi perah adalah kondisi bahaya (baik bahaya alam maupun bahaya buatan) yang dapat menimbulkan risiko kerugian pada usaha ternak sapi perah. Penelitian ini bertujuan untuk mengevaluasi dampak dari konteks kerentanan usaha ternak sapi perah terhadap kelembagaan peternak dan pengembangan usaha ternak sapi perah. Penelitian dilakukan di Kelompok Usaha Bersama (KUB) Tirtasari Kresna Gemilang, Kabupaten Malang, Jawa Timur. Responden adalah semua peternak yang tergabung di dalam KUB Tirtasari Kresna Gemilang, yaitu sebanyak 174 orang. Data dianalisis menggunakan metode PLS (Partial Least Square) dengan aplikasi SmartPLS. Hasil penelitian menunjukkan bahwa konteks kerentanan berpengaruh negatif terhadap kelembagaan peternak dan pengembangan usaha ternak sapi perah, serta kelembagaan peternak berpengaruh positif terhadap pengembangan usaha ternak sapi perah Kesimpulan penelitian ini yaitu pengembangan usaha ternak dipengaruhi oleh konteks kerentanan dan kelembagaan peternak sapi perah. Saran yang harus diperhatikan peternak dan kelembagaan peternak sapi perah ialah aspek kerentanan yang meliputi fluktuasi harga jual susu segar, kebijakan pemerintah, kebijakan kelompok, dan moralitas peternak di dalam kelompok.

\section{Pendahuluan}

Keputusan Menteri Pertanian Republik Indonesia tahun 2015 Nomor 43/Kpts/PD.010/1/2015 tentang Penetapan Kawasan Sapi Potong, Kerbau, Kambing, Sapi Perah, Domba, dan Babi Nasional menetapkan bahwa penetapan kawasan sapi perah nasional terdapat di Kabupaten Bandung, Kabupaten Bandung Barat, Kabupaten Semarang, Kabupaten Salatiga, Kabupaten Malang, dan Kota Batu.

Populasi ternak sapi perah di Kabupaten Malang mencapai 81.150 ekor atau setara dengan $14,75 \%$ populasi ternak sapi perah nasional yang mencapai 550.141 ekor (Badan Pusat Statistik, 2018), sehingga upaya untuk menjaga dan mengembangkan usaha ternak sapi perah di Kabupaten Malang sangat rasional. Berbagai upaya dilakukan pemerintah untuk meningkatkan produktivitas sapi perah diantaranya dengan mengeluarkan Pedoman Pembibitan Sapi Perah yang Baik melalui Peraturan Menteri Pertanian Republik Indonesia Nomor 100/Permentan/OT.140//7/2014.

Upaya pengembangan potensi ternak sapi perah salah satunya dengan cara meningkatkan ketersediaan pakan, pengetahuan peternak, permintaan susu, pendapatan peternak, infrastruktur pasar, peranan lembaga, dukungan kebijakan pemerintah (Elida, 2016). Muslihatinningsih (2013) menyebutkan bahwa strateg penambahan modal usaha ternak sapi perah dapat meningkatkan jumlah sapi perah dan produksi susu, sehingga strategi tersebut sesuai dengan peningkatan produktivitas dan pengembangan kapasitas melalui investasi.

Berbagai upaya strategi dan pengembangan usaha ternak sapi perah dilakukan untuk mendukung produktivitas usaha ternak sapi perah (Amam et al., 2019a), namun dampak yang ditimbulkan dari konteks kerentanan usaha ternak sapi perah tidak pernah dikaji. Konteks kerentanan pada penelitian terdahulu dipengaruhi oleh aksesibilitas peternak terhadap sumber daya (Amam et al., $2019^{\mathrm{b}}$ ). Kerentanan dalam usaha ternak sapi perah adalah kondisi bahaya (baik bahaya alam maupun bahaya buatan) yang dapat menimbulkan risiko kerugian pada usaha ternak sapi perah. Konteks kerentanan yang akan dievaluasi pada penelitian ini berdasarkan pengembangan usaha ternak sapi perah dan aspek kelembagaan peternak. Amam dan Soetriono (2019) menyebutkan bahwa peranan kelembagaan peternak bukan hanya untuk tindakan preventif bagi para peternak untuk meminimalkan risiko bisnis, tetapi juga bertujuan untuk pengembangan usaha ternak sebagai upaya dalam mendukung kesejahteraan masyarakat.

Berdasarkan uraian di atas, tujuan penelitian ialah mengevaluasi dampak dari konteks kerentanan usaha ternak sapi perah terhadap kelembagaan peternak dan aspek pengembangan usaha ternak sapi perah, sehingga bermanfaat terhadap penguatan kelembagaan dan pengembangan usaha ternak sapi perah di lokasi kawasan sapi perah nasional, khususnya di Kabupaten Malang.

\section{Metode}

Penelitian dilakukan pada bulan Oktober hingga Desember tahun 2018 di Kelompok Usaha Bersama (KUB) Tirtasari Kresna Gemilang, Kabupaten Malang. KUB Tirtasari Kresna Gemilang dipilih secara purposive sampling karena merupakan kelembagaan peternak sapi perah yang sudah memiliki Badan Hukum Nomor 0010084-AH.01.07. KUB Tirtasari Kresna Gemilang terdiri dari 174 peternak sapi perah dengan produksi susu mencapai 76.079 liter.

Responden penelitian adalah semua peternak sapi perah di KUB Tirtasari Kresna Gemilang (total sampling), yaitu 174 orang. Data diperoleh dengan menggunakan metode pengisian angket (kuisioner) berskala likert +1 sampai dengan +5 , selain itu data juga diperoleh dengan metode wawancara dan observasi sebagai pengamatan langsung untuk mendapatkan tambahan informasi dari responden. Variabel penelitian terdiri dari 3 variabel laten dengan 17 indikator (Tabel 1). Variabel laten terdiri dari konteks kerentanan, kelembagaan peternak, dan aspek pengembangan usaha ternak sapi perah. Data dianalisis menggunakan metode PLS (Partial Least Square) dengan aplikasi SmartPLS Uji struktural di dalam metode PLS terdiri dari beberapa kriteria, diantaranya nilai AVE (Average Variance Extracted), nilai CR (Composite Reliability), nilai $\mathrm{R}$ Square $\left(\mathrm{R}^{2}\right)$, dan nilai CA (Cronbach Alpha's). Uji model atau uji pengaruh dalam metode PLS meliputi koefisien determinasi $\left(\mathrm{R}^{2}\right)$, $\mathrm{t}$-statistik, dan koefisien parameter.

Tabel 1. Variabel dan Indikator Penelitian

Indikator Konteks Kerentanan $\left(\mathrm{X}_{1}\right)$

musim (kondisi tidak pasti)

keamanan (pencurian ternak)

penyakit dan kesehatan ternak

fluktuasi harga jual susu segar

kebijakan pemerintah

kebijakan kelompok (KUB Tirtasari Kresna Gemilang)

moralitas peternak di dalam kelompok

Indikator Faktor Kelembagaan Peternak $\left(Z_{1}\right)$

sarana kelompok peternak

capaian tujuan kelompok ( $g o a l$ )

fungsi dan tugas kelompok

struktur kelompok

kerukunan sesama anggota kelompok

bentuk kelembagaan kelompok

Indikator Pengembangan Usaha Ternak Sapi Perah ( $\left.\mathrm{Y}_{1}\right)$

peningkatan pendapatan

peningkatan populasi ternak

penambahan tenaga kerja

penambahan kandang (unit produksi) Notasi

$\mathrm{X}_{1.1}$

Notasi

\section{Hasil dan Pembahasan}

\section{Pengujian Indikator}

Indikator yang digunakan di dalam penelitian diuji menggunakan SmartPLS. Indikator yang memenuhi syarat atau valid ialah indikator yang memiliki nilai Outer Loading $>0.500$, sedangkan untuk indikator dengan nilai Outer Loading $<0.500$ dianggap tidak valid atau tidak memenuhi syarat. Hasil pengujian indikator tersebut diuraikan pada Tabel 2.

Data Tabel 2 menunjukkan bahwa: 1) indikator valid dari variabel konteks kerentanan ialah: a) fluktuasi harga jual susu segar, b) kebijakan pemerintah, c) kebijakan kelompok, dan d) moralitas peternak di dalam kelompok; 2) indikator valid dari faktor kelembagaan peternak ialah: a) sarana kelompok peternak, b) capaian tujuan kelompok, c) fungsi dan tugas kelompok, serta d) struktur kelompok; dan 3) indikator valid dari variabel aspek pengembangan usaha ternak sapi perah ialah: a) penambahan tenaga kerja, dan b) penambahan kandang.

\section{Pengujian Struktural}

Uji struktural pada variabel laten yang terdiri dari konteks kerentanan usaha ternak sapi perah, kelembagaan peternak, dan aspek pengembangan usaha ternak diantaranya terdiri dari nilai Average Variance Extracted (AVE), Composite Reliability (CR), nilai $R$ Square $\left(\mathrm{R}^{2}\right)$, dan nilai Cronbach's Alpha (CA). Uji struktural dengan menggunakan SmartPLS didapatkan hasil pada Tabel 3. 
Tabel 2. Nilai Outer Loading

\begin{tabular}{ccccc}
\hline Notasi & $\mathrm{X}_{1}$ & $\mathrm{Z}_{1}$ & $\mathrm{Y}_{1}$ & Hasil \\
\hline $\mathrm{X}_{1.1}$ & -0.225 & & & tidak valid \\
$\mathrm{X}_{1.2}$ & -0.007 & & & tidak valid \\
$\mathrm{X}_{1.3}$ & -0.179 & & & tidak valid \\
$\mathrm{X}_{1.4}$ & 0.789 & & & valid \\
$\mathrm{X}_{1.5}$ & 0.760 & & & valid \\
$\mathrm{X}_{1.6}$ & 0.849 & & & valid \\
$\mathrm{X}_{1.7}$ & 0.757 & & & valid \\
$\mathrm{Y}_{1.1}$ & & & 0.550 & valid \\
$\mathrm{Y}_{1.2}$ & & & 0.745 & valid \\
$\mathrm{Y}_{1.3}$ & & & 0.863 & valid \\
$\mathrm{Y}_{1.4}$ & & & 0.752 & valid \\
$\mathrm{Y}_{1.5}$ & & & -0.502 & tidak valid \\
$\mathrm{Y}_{1.6}$ & & & 0.393 & tidak valid \\
$\mathrm{Z}_{1.1}$ & & 0.315 & & tidak valid \\
$\mathrm{Z}_{1.2}$ & & 0.380 & & tidak valid \\
$\mathrm{Z}_{1.3}$ & & 0.667 & & valid \\
$\mathrm{Z}_{1.4}$ & & 0.830 & & valid \\
\hline
\end{tabular}

Sumber: Output SmartPLS

Tabel 3. Uji Struktural

\begin{tabular}{lcccc}
\hline & $\begin{array}{c}\text { Average Variance } \\
\text { Extracted }\end{array}$ & $\begin{array}{c}\text { Composite } \\
\text { Reliability }\end{array}$ & R Square Cronbach's Alpha \\
\hline $\mathrm{X}_{1}$ & 0.682 & 0.895 & & 0.851 \\
$\mathrm{Z}_{1}$ & 0.563 & 0.833 & 0.184 & 0.743 \\
$\mathrm{Y}_{1}$ & 0.572 & 0.718 & 0.230 & 0.781 \\
\hline
\end{tabular}

Sumber: Output SmartPLS

Uji model pada uji pengaruh setelah uji indikator pada variabel laten yang terdiri dari konteks kerentanan usaha ternak sapi perah, kelembagaan peternak, dan aspek pengembangan usaha ternak yang terdiri dari nilai $\mathrm{R}^{2}$ (koefisien determinasi), nilai t statistik, dan nilai koefisien parameter. Uji model dengan menggunakan SmartPLS didapatkan hasil pada Tabel 4.

Tabel 4. Uji Model

\begin{tabular}{lc}
\hline \multicolumn{1}{c}{ Pengujian } & Hasil Uji \\
\hline Koefisien Determinasi $\left(\mathrm{R}^{2}\right)$ & \\
kelembagaan peternak sapi perah & 0.184 \\
aspek pengembangan usaha ternak sapi & 0.230 \\
perah & \\
t-statistik & \\
$\mathrm{X}_{1} \rightarrow \mathrm{Z}_{1}$ & 6.810 \\
$\mathrm{X}_{1} \rightarrow \mathrm{Y}_{1}$ & 3.041 \\
$\mathrm{Z}_{1} \rightarrow \mathrm{Y}_{1}$ & 4.747 \\
Koefisien Parameter & \\
$\mathrm{X}_{1} \rightarrow \mathrm{Z}_{1}$ & -0.429 \\
$\mathrm{X}_{1} \rightarrow \mathrm{Y}_{1}$ & -0.359 \\
$\mathrm{Z}_{1} \rightarrow \mathrm{Y}_{1}$ & 0.353 \\
\hline Sumber: Output SmartPLS &
\end{tabular}

Sumber: Output SmartPLS

Uji model pada Tabel 4 menunjukkan bahwa konteks kerentanan usaha ternak sapi perah berpengaruh negatif terhadap kelembagaan peternak dan pengembangan usaha ternak sapi perah, dan kelembagaan peternak berpengaruh positif terhadap pengembangan usaha ternak sapi perah. Amam dan Soetriono (2019) menyatakan bahwa performa kelembagaan berpengaruh negatif terhadap risiko bisnis usaha ternak sapi perah, namun berpengaruh positif terhadap pengembangan usaha ternak sapi perah. Artinya bahwa faktor kelembagaan peternak di dalam model mempunyai pengaruh yang mendukung pengembangan usaha ternak sapi perah. Uji model tersebut ditunjukkan pada Gambar 1.

\section{Dampak Konteks Kerentanan terhadap Kelembagaan Peternak}

Aspek kerentanan usaha ternak sapi perah berpengaruh negatif signifikan terhadap kelembagaan peternak sebesar - 0.430 . Artinya bahwa semakin tinggi konteks kerentanan usaha ternak di Kelompok Usaha Bersama (KUB) Tirtasari Kresna Gemilang, maka kualitas kelembagaan semakin rendah. Konteks kerentanan yang terdapat di KUB Tirtasari Kresna Gemilang ialah fluktuasi harga jual susu segar, kebijakan pemerintah, kebijakan kelompok, dan moralitas peternak di dalam kelompok.

Fluktuasi harga jual susu segar saat rendahnya harga jual susu segar berdampak pada minimnya sarana dan prasarana kelembagaan. Hal tersebut karena di lokasi penelitian, sebagian keuntungan dari penjualan susu segar disisihkan untuk kas kelompok. Rendahnya harga jual susu segar mengakibatkan kas kelompok menjadi sedikit, sehingga daya beli kelompok terhadap fasilitas, sarana, dan prasarana menjadi berkurang. Harga jual susu segar yang rendah berdampak pada tidak tercapainya tujuan kelompok. Anantanyu (2011) menjelaskan bahwa salah satu fungsi kelembagaan yaitu mampu memperbaiki taraf hidup, harkat, dan martabat. Artinya, rendahnya harga jual susu segar berdampak pada ketidakjelasan fungsi dan tugas kelompok untuk memperbaiki taraf hidup, harkat, dan martabat anggotanya. Hal tersebut mempengaruhi struktur organisasi di dalam kelompok.
Dukungan pemerintah dan kebijakan pemerintah yang dianggap kurang mendukung kelembagaan peternak sapi perah berdampak pada minimnya sarana dan prasarana kelembagaan, tidak tercapainya tujuan kelompok, tidak berjalannya fungsi dan tugas kelompok, serta tidak jelasnya struktur kelembagaan. Wahyuni (2017) menyebutkan bahwa kelembagaan petani atau peternak membutuhkan dukungan dari berbagai pihak. Hal tersebut tertuang di dalam Undang-undang Nomor 19 tahun 2013 tentang Perlindungan dan Pembinaan Petani.

Dukungan kelompok dan kebijakan kelompok yang dianggap kurang memeperhatikan kesejahteraan anggotanya berdampak pada minimnya sarana dan prasarana kelembagaan, tidak tercapainya tujuan kelompok, tidak berjalannya fungsi dan tugas kelompok, serta tidak jelasnya struktur kelembagaan. Mukson et al. (2012) menyatakan bahwa lingkungan sosial, ekonomi, kelembagaan, dan lingkungan usaha perlu diperhatikan dalam upaya untuk meningkatkan produktivitas usaha dan pendapatan peternak. Salah satu upaya dukungan kelompok ialah meningkatkan posisi tawar peternak (Nasrul, 2012) dan adopsi teknologi. Adopsi teknologi pada level rendah menyebabkan peningkatan produktivitas, hal tersebut terjadi pada organisasi atau perusahaan dengan sumber daya yang melimpah (Ellitan, 2003).

Moralitas peternak yang rendah di dalam kelompok berdampak pada minimnya sarana dan prasarana kelembagaan, tidak tercapainya tujuan kelompok, tidak berjalannya fungsi dan tugas kelompok, serta tidak jelasnya struktur kelembagaan. Suswandi dan Sutarno (2017) menjelaskan bahwa dinamika kelompok tani yang baik, terlihat dari kuatnya faktor-faktor kekuaatan yang mampu menggerakkan perilaku anggota kelompok untuk mencapai tujuan secara efektif dan efisien.

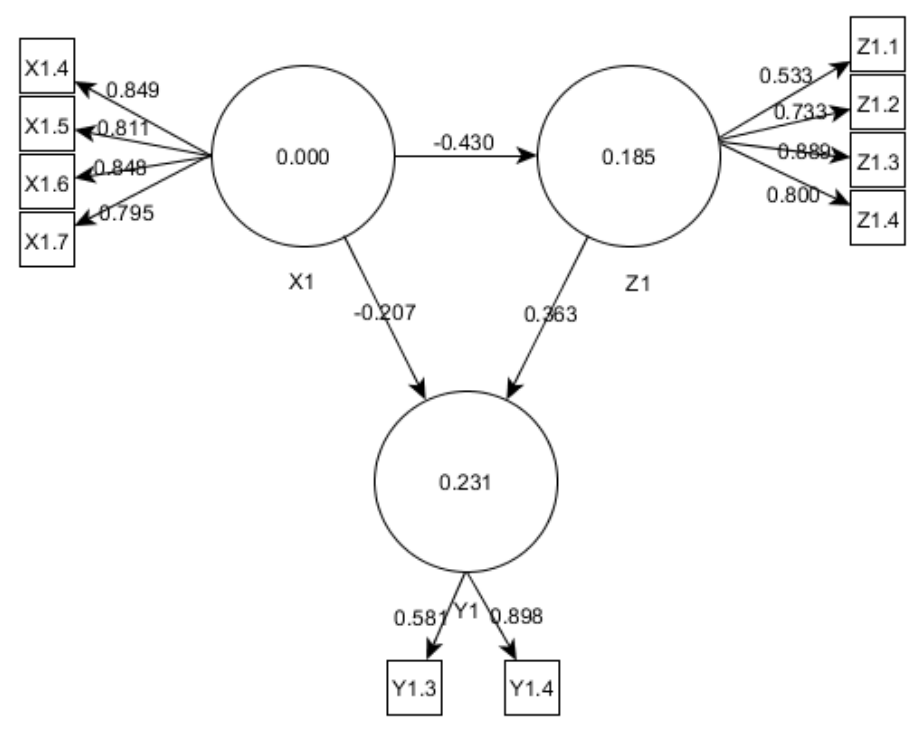

Gambar 1. Hasil Logaritma SmartPLS

\section{Dampak Konteks Kerentanan terhadap Pengembangan Usaha} Ternak Sapi Perah

Aspek kerentanan usaha ternak sapi perah berpengaruh negatif signifikan terhadap pengembangan usaha ternak sapi perah sebesar -0.207. Artinya bahwa semakin tinggi konteks kerentanan usaha ternak di Kelompok Usaha (KUB) Tirtasari Kresna Gemilang, maka pengembangan usaha ternak sapi perah semakin rendah. Konteks kerentanan yang terdapat di KUB Tirtasari Kresna Gemilang ialah fluktuasi harga jual susu segar, kebijakan pemerintah, kebijakan kelompok, dan moralitas peternak di dalam kelompok

Fluktuasi harga jual susu segar saat rendahnya harga jual susu segar berdampak pada tidak bertambahnya tenaga kerja dan tersendatnya penambahan unit produksi (kandang). Hal tersebut disebabkan karena keuntungan peternak belum bisa memenuhi aspek pengembangan usaha. Priyanti dan Saptati (2008) mengungkapkan bahwa harga susu dalam negeri sangat kompetitif dibandingkan dengan harga susu dunia, sehingga IPS (Industri Pengolahan Susu) lebih memilih pasokan susu dalam negeri untuk memenuhi kebutuhan bahan baku industri. Farid dan Sukesi (2011) menjelaskan bahwa dampak yang ditimbulkan dari tingginya impor susu ialah menguras devisa negara, tidak menjamin keamanan pangan jangka panjang, meningkatkan pengangguran dan menurukan kesejahteraan masyarakat, serta menurunkan konsumsi susu segar yang berkualitas berbahan baku SSDN (Susu Segar Dalam Negeri). Hal tersebut menunjukkan bahwa rendahnya harga jual susu segar berdampak pada rendahnya pengembangan usaha ternak sapi perah di KUB Tirtasari Kresna Gemilang, sedangkan tingginya harga jual susu segar berdampak pada tingginya harga beli konsentrat pakan ternak (Priyanti dan Saptati, 2008).

Dukungan pemerintah dan kebijakan pemerintah yang dianggap kurang mendukung kelembagaan peternak sapi perah berdampak pada tidak 
bertambahnya tenaga kerja dan tersendatnya penambahan unit produksi (kandang). Hermanto (2018) menyebutkan bahwa penguatan kelembagaan merupakan salah satu upaya untuk menghadapi tantangan pertanian di masa depan. Salah satu upaya penguatan kelembagaan ialah daya dukung pemerintah dengan upaya pemberdayaan kelembagaan pertanian dan perdesaan diperlukan sebagai upaya penciptaan kemandirian petani, peningkatan pendapatan rumah tangga, dan pengembangan agribisnis pertanian (Elizabeth, 2007). Pentingnya dukungan pemerintah dapat meningkatkan pengembangan usaha ternak sapi perah di KUB Tirtasari Kresna Gemilang. Pengembangan usaha ternak melalui peningkatan populasi sapi perah dapat dilakukan pada suatu daerah yang didukung oleh potensi daerah tersebut. Potensi daerah untuk pengembangan sapi perah dapat ditingkatkan dengan penyediaan pakan, pengetahuan peternak, permintaan susu, pendapatan peternak, infrastruktur pasar, peranan lembaga pemberi kredit, dan kebijakan pemerintah lokal (Santosa et al., 2013).

Dukungan kelompok dan kebijakan kelompok yang dianggap kurang memeperhatikan kesejahteraan anggotanya berdampak pada tidak bertambahnya tenaga kerja dan tersendatnya penambahan unit produksi (kandang). Sutarto $e$ al. (2010) menyatakan bahwa salah satu strategi kelompok untuk mencapai tujuan ialah meningkatkan posisi penawaran. Artinya bahwa, kebijakan kelompok untuk mensejahterakan anggota dengan cara meningkatkan harga jual susu segar, sehingga upaya pengembangan usaha ternak sapi perah bisa terwujud di KUB Tirtasari Kresna Gemilang.

Moralitas peternak yang rendah di dalam kelompok berdampak pada tidak bertambahnya tenaga kerja dan tersendatnya penambahan unit produksi (kandang). Amam dan Soetriono (2019) menjelaskan bahwa SDM (Sumber Daya Manusia) peternak sapi perah mempunyai peranan penting karena merupakan individu yang bekerja sebagai penggerak usaha ternak sapi perah, sehingga sapi perah mempunyai kemampuan untuk memproduksi susu yang tinggi. SDM peternak yang tinggi dapat meningkatkan pengembangan usaha ternak sapi perah di KUB Tirtasari Kresna Gemilang.

\section{Pengembangan Usaha Ternak Sapi Perah}

Konteks kerentanan dan kelembagaan peternak mempengaruhi pengembangan usaha ternak sapi perah sebesar $23,1 \%$, sedangkan sisanya sebesar $76,9 \%$ dipengaruhi oleh faktor lain yang tidak terdapat di dalam model. Pengembangan usaha ternak dipengaruhi oleh tingkat pendapatan peternak sapi perah, sedangkan pendapatan peternak dipengaruhi oleh curahan tenaga kerja dan jumlah kepemilikan ternak. Taslim (2011) mengungkapkan bahwa jumlah kepemilikan ternak merupakan faktor dominan yang paling berpengaruh terhadap pendapatan peternak. Upaya untuk meningkatkan pendapatan peternak juga dilakukan dengan cara meningkatkan peranan kelembagaan. Salah satu tujuan kelembagaan adalah untuk memfasilitasi penyediaan kredit bagi peternak dan mengatur perdagangan pakan ternak (Kalangi et al., 2014).

Hidayah (2011) menyebutkan bahwa pendidikan peternak, ketersediaan air, dan jumlah kepemilikan sapi berpengaruh sangat nyata terhadap pengembangan usaha peternakan sapi perah, sedangkan pengalaman beternak berpengaruh nyata terhadap pengembangan usaha peternakan sapi perah. Suresti dan Wati (2012) menjelaskan bahwa pengembangan usaha ternak ditujukan untuk meningkatkan ketahanan pangan dan peningkatan daya beli masyarakat melalui perbaikan pendapatan. Pengembangan usaha ternak sapi perah di KUB Tirtasari Kresna Gemilang dipengaruhi secara positif oleh kelembagaan peternak. Pengembangan usaha ternak melalui peningkatan populasi sapi perah dapat dilakukan pada suatu daerah yang didukung oleh potensi daerah tersebut. Potensi daerah untuk pengembangan sapi perah dapat ditingkatkan dengan penyediaan pakan, pengetahuan peternak, permintaan susu, pendapatan peternak, infrastruktur pasar, peranan lembaga pemberi kredit, dan kebijakan pemerintah lokal (Santosa et al., 2013). Amam dan Harsita (2019) menyebutkan bahwa pengembangan usaha ternak dapat mempengaruhi SDM peternak sapi perah.

\section{Simpulan}

Konteks kerentanan berpengaruh negatif terhadap kelembagaan peternak dan pengembangan usaha ternak sapi perah, serta kelembagaan peternak berpengaruh positif terhadap pengembangan usaha ternak sapi perah Pengembangan usaha ternak dipengaruhi oleh konteks kerentanan dan kelembagaan peternak sapi perah. Konteks kerentanan tersebut meliputi fluktuasi harga jual susu segar, kebijakan pemerintah, kebijakan kelompok, dan moralitas peternak di dalam kelompok, sedangkan kelembagaan peternak meliputi sarana kelompok, capaian tujuan kelompok, fungsi dan tugas kelompok, serta struktur kelompok

\section{Pustaka}

Amam, M. W. Jadmiko, P. A. Harsita, dan M. S. Poerwoko. 2019ª . Model Pengembangan Usaha Ternak Sapi Perah Berdasarkan Faktor Aksesibilitas Sumber Daya. Jurnal Sain Peternakan Indonesia. 14 (1): 61-69.

Amam, M. W. Jadmiko, P. A. Harsita, N. Widodo, dan M. S. Poerwoko. 2019 ${ }^{\text {b }}$ Sumber Daya Internal Peternak Sapi Perah dan Pengaruhnya terhadap Dinamika Kelompok dan Konteks Kerentanan. 7 (1): 192-200.

Amam dan P. A. Harsita. 2019. Efek Domino Performa Kelembagaan, Aspek Risiko Bisnis, dan Pengembangan Usaha terhadap SDM Peternak Sapi Perah. Sains Peternakan. 17 (1): 5-11.

Amam dan Soetriono. 2019. Evaluasi Performa Kelembagaan Peternak Sapi Perah Berdasarkan Aspek Risiko Bisnis dan Pengembangan Usaha. 6 (1): $8-13$.
Anantanyu, S. 2011. Kelembagaan Petani: Peran dan Strategi Pengembangan Kapasitasnya. Jurnal SEPA. 7 (2): 102-109.

Elida, S. 2016. Potensi dan Strategi Pengembangan Usaha Ternak Sapi Perah di Kecamatan Pangkalan Kerinci Kabupaten Pelalawan. Gontor Agrotech Science Journal. 2 (2): 53-70.

Elizabeth, R. 2007. Penguatan dan Pemberdayaan Kelembagaan Petani Mendukung Pengembangan Agribisnis Kedelai. Pusat Analisis Sosial Ekonomi dan Kebijakan Pertanian. 165-173.

Ellitan, L. 2003. Peran Sumber Daya dalam Meningkatkan Pengaruh Teknologi terhadap Produktivitas. Jurnal Manajemen dan Kewirausahaan. 5 (2): 155-170.

Farid, M. dan Sukesi, H. 2011. Pengembangan Susu Segar dalam Negeri untuk Pemenuhan Kebutuhan Susu Nasional. Buletin Ilmiah Litbang Perdagangan. 5 (2): 196-221.

Hermanto. 2018. Pengentasan Kemiskinan di Perdesaan: Pengembangan SDM, Penguatan Usaha, dan Inovasi Pertanian. Forum Penelitian Agro Ekonomi. 35(2): 139-150.

Hidayah, N. 2011. Strategi Pengembangan Usaha Peternakan Sapi Perah di Kabupaten Boyolali. Disertasi Program Doktor Ilmu Peternakan. Fakultas Peternakan Universitas Gadjah Mada.

Kalangi, L. S., Syaukat, Y., Kuntjoro, S. U., dan Priyanti, A. 2014. Technical Efficiency of Beef Cattle Breeding Business in East Java Province. Media Peternakan. 37 (2): 136-142.

Mukson, M. Isbandi, Santosa, S. I., Sudjadmogo, Setiadi, A. 2012. Analysis of Various Factors in Order to Enhance Productivity and Income of Diary Cattle Farmers in Central Java, Indonesia. Journal of The Indonesian Tropical Animal Agriculture. 37(3): 220-208.

Muslihatinningsih, F. 2013. Strategi Pengembangan Klaster Peternakan Sapi Perah yang Ideal di Kecamatan Sumberbaru Kabupaten Jember Tahun 2013. Jurnal Ekonomi Pembangunan. 1-10.

Nasrul, W. 2012. Pengembangan Kelembagaan Pertanian untuk Meningkatkan Kapasitas Petani terhadap Pembangunan Pertanian. Menara Ilmu. III(29): 166-174.

Priyanti, A. dan Saptati, A. 2008. Dampak Harga Susu Dunia terhadap Harga Susu Dalam Negeri Tingkat Peternak: Kasus Koperasi Peternak Sapi Bandung Utara di Jawa Barat. Seminar Nasional Dinamika Pembangunan Pertanian dan Perdesaan: Tantangan dan Peluang bagi Peningkatan Kesejahteraan Petani. Bogor. pp. 1-10.

Santosa, S. I., Setiadi, A., dan Wulandari, R. 2013. Analisis Potens Pengembangan Usaha Peternakan Sapi Perah dengan Menggunakan Paradigma Agribisnis di Kecamatan Musuk Kabupaten Boyolali. Buletin Peternakan. 37 (2): 125-135.

Suresti, A. dan Wati, R. 2012. Strategi Pengembangan Usaha Peternakan Sapi Potong di Kabupaten Pesisir Selatan. Jurnal Peternakan Indonesia. 14 (1): 249-262.

Suswandi dan Sutarno. 2017. Analisa Dinamika dan Kemandirian Kelembagaan Ekonomi Petani dengan Penerapan Pertanian Organik Bersertifikasi di Kabupaten Boyolali. Prosiding Seminar Nasional. pp. 220-240.

Sutarto, Padmaningrum, D., dan Wibowo, A. 2010. Kajian Kelembagaan Agribisnis Wortel untuk Mendukung Pengembangan Kawasan Agropolitan Suthomadansih di Kabupaten Karanganyar. Caraka Tani. 25 (1): 87-94.

Taslim. 2011. Pengaruh Faktor Produksi Susu Usaha Ternak Sapi Perah Melalui Pendekatan Analisis Jalur di Jawa Barat. Jurnal Ilmu Ternak. 10(1): 52 56.

Wahyuni, D. 2017. Penguatan Kelembagaan Petani Menuju Kesejahteraan Petani. Jurnal Kesejahteraan Sosial. IX (17): 9-12. 